\title{
Phylogenetic Analysis of Fusarium oxysporum f. sp. cubense Associated with Fusarium Wilt of Bananas from Peninsular Malaysia
}

(Analisis Filogenetik Fusarium oxysporum f. sp. cubense Berkait dengan Penyakit Layu

Fusarium Pisang dari Semenanjung Malaysia)

\section{Clement KiIng Fook Wong, DZarifah Zulperi*, GAnesan Vadamalai, NoOR Baity Saidi \& Chui Yao TeH}

\begin{abstract}
Fusarium wilt of bananas caused by Fusarium oxysporum $f$. sp. cubense (Foc) has been known to hamper banana production. In Malaysia, most of the edible banana cultivars are susceptible to the fungal strain Foc tropical race 4 (Foc TR4). To date, molecular characterisation of Foc TR4 in this country remains elusive. Thus, this study aimed to characterise the diversity of FOC TR4 in Peninsular Malaysia based on the phylogenetic analysis of transcription elongation factor (TEF-1 $\alpha$ ) sequences. From March 2016 to December 2016, 17 isolates of Foc were isolated from nine outbreak states in Peninsular Malaysia consisting of Penang, Perak, Selangor, Negeri Sembilan, Melaka, Johor, Pahang, Kelantan and Terengganu, with disease incidence exceeding $70 \%$ in several plantations. Morphological, molecular identification using TR4 specific primers and pathogenicity assay confirmed the identity of the fungal pathogen. Pathogenicity assays indicated that the aggressiveness level varies among the isolates. Phylogenetic analyses of TEF1- $\alpha$ sequences showed that there was no genetic variation among the Foc isolates by clustering them into four vegetative compatibility groups (VCGS) of 01213 (TR4), 01216 (TR4), $01213 / 16$ (TR4) and 0121 (R4). PCR amplification using VCG specific primers have further categorised 16 Foc isolates as VCG01213 and a single isolate as VCG01213/16. In addition, no correlation between TEF-1 $\alpha$ sequences and aggressiveness of isolates could be established.
\end{abstract}

Keywords: Aggressiveness; banana; fusarium wilt; phylogenetic analysis; TEF-1 $\alpha$

ABSTRAK

Penyakit layu Fusarium pisang disebabkan oleh kulat Fusarium oxysporum $f$. sp. cubense (Foc) telah menjejaskan pengeluaran pisang. Kebanyakan kultivar pisang yang boleh dimakan di Malaysia mudah dijangkiti oleh strain kulat Foc tropical race 4 (Foc TR4). Sehingga kini, pencirian Foc TR4 di peringkat molekul dalam negara ini masih tidak dikaji. Justeru, kajian ini bertujuan untuk mencirikan kepelbagaian Foc TR4 di Semenanjung Malaysia berdasarkan

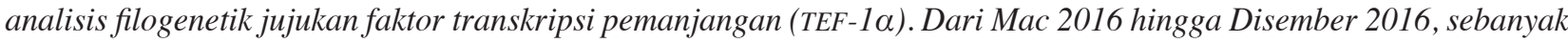
17 pencilan Foc telah dipencilkan dari sembilan kawasan berpenyakit di Semenanjung Malaysia terdiri daripada Pulau Pinang, Perak, Selangor, Negeri Sembilan, Melaka, Johor, Pahang, Kelantan dan Terengganu dengan kejadian penyakit melebihi $70 \%$ di beberapa ladang pisang. Pengenalpastian morfologi dan molekul dengan menggunakan primer khusus TR4 dan ujian kepatogenan telah mengesahkan identiti patogen kulat. Ujian kepatogenan menunjukkan bahawa tahap agresif antara pencilan Foc adalah berbeza. Analisis filogenetik jujukan TEF-1a menunjukkan bahawa tiada variasi genetik antara pencilan Foc dengan dibahagikan kepada empat vegetative compatibility groups (VCGs) iaitu 01213 (TR4), 01216 (TR4), 01213/16 (TR4) dan 0121 (R4). Amplifikasi PCR dengan menggunakan primer khusus VCG telah selanjutnya mengkategorikan 16 pencilan Foc sebagai VCG01213 dan satu pencilan sebagai VCG01213/16. Tambahan pula, tiada korelasi antara jujukan TEF-1 $\alpha$ dan tahap agresif pencilan Foc dapat ditunjukkan.

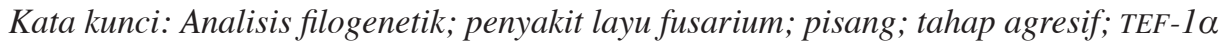

\section{INTRODUCTION}

Fusarium wilt of bananas or Panama disease is caused by the fungal pathogen Fusarium oxysporum f. sp. cubense (Foc). The disease has severely reduced banana production worldwide since currently there are no effective means of controlling the disease spread (Visser et al. 2010). This pathogen produces asexual reproductive structures known as chlamydospores in the absence of its host which enables the fungus to persist for up to 30 years in the soil (Ploetz 2006). The pathogenicity of Foc strains can be categorised based on the ability to cause disease to a particular set of cultivars. Races 1 and 2 are virulent to Gros Michel (AAA) and Bluggoe (ABB), respectively (Stover 1972). On the other hand, race 4 is the most virulent strain which infects Cavendish (AAA) as well as Gros Michel and Bluggoe (Ploetz et al. 1990). Race 4 was first detected in 1980s in Taiwan followed by Australia and Africa. In 1990s, the pathogen was reported in Malaysia and Indonesia (Buddenhagen 2009). The race 4 isolates are further divided into subtropical race 4 (ST4) and tropical race 4 
(TR4). The ST4 strains infect Cavendish in the subtropics and the TR4 strains are pathogenic in both tropical and subtropical regions (Buddenhagen 2009). The Cavendish plantations in Malaysia and Indonesia were wiped out by the TR4 strains in 1990s and have since been a continuous threat in commercial banana plantations in Southeast Asia (Ploetz 2015).

Vegetative compatibility group (VCG) is another useful means of subdividing Foc into 24 unique VCGs (VCG0120 to VCG0126 and VCG0128 to VCG01224) (Katan 1999). Generally, isolates grouped within the same VCG are genetically related and can form a stable heterokaryon by hyphal fusion (Puhalla 1985). At least 9 vCGs were found distributed in Malaysia including VCGs 0120-01215, 0121, 0123, 0124-01220, 01213-01216, 01213-01216, 0120-01215, 01217 and 01218 (Ploetz 2015). However, subdividing Foc into VCGs or race may not be accurate to characterise the genetic relatedness between Foc isolates (Fourie et al. 2009). For example, all isolates of TR4 belongs to VCGs 01213-01216 but ST4 isolates are classified into five VCGs (VCGs 0121, 0122, 0129, 012001215, 01211) (Buddenhagen 2009). Therefore, DNA-based methods provide alternative approaches to discern the genetic diversity within and between Foc populations.

Molecular characterisation of the genetic variability of pathogen isolated from various geographical regions is required to strategise and adopt efficient management strategies (Kumar et al. 2006). DNA-based phylogenetic studies have successfully separated 70 Foc isolates worldwide into two distinct clades and eight lineages by combining and analysing the datasets of translation elongation factor (TEF1- $\alpha$ ), mitochondrial small subunit (MtSSU) and intergenic spacer (IGS) sequences (Fourie et al.2009). The analysis also indicated that most isolates that shared the same VCGs were clustered together. Intraspecific variations of Foc isolates in Malaysia have also been demonstrated via sequence analysis of TEF- $1 \alpha$ genes (Leong et al. 2010). Nonetheless, the VCG designation per isolate was not known. Furthermore, the phylogenetic data reported by Leong et al. (2010) did not carry out morphological characterisation and pathogenicity assays on the Foc isolates prior to phylogenetic analysis. Hence, this study was undertaken to first identify Foc isolates from Peninsular Malaysia via standard morphological, molecular identification and pathogenicity assays. This study also sought to resolve the genetic relationship between Malaysian Foc isolates and other reported VCGs of Foc as reported by Fourie et al. (2009) by sequence analysis of TEF- $1 \alpha$ gene.

\section{MATERIALS AND METHODS}

\section{ISOLATION OF FUNGAL PATHOGEN}

A total of 17 isolates of Foc were isolated from symptomatic banana plants from nine states in Malaysia. During the collection of infested samples, a random sampling technique was used. To isolate Foc, discoloured roots, corms and vascular tissues showing wilting symptoms were surfacesterilised, excised and plated on water agar for 4 to 5 days at room temperature to reduce bacterial contamination. For soil samples, $10 \mathrm{~g}$ of soil was added into $100 \mathrm{~mL}$ of sterile distilled water. The soil suspension was agitated for $1 \mathrm{~h}$ at $200 \mathrm{rpm}$. Lastly, the suspension was serially diluted and plated on Komada's medium (Komada 1975) and incubated for 3 to 4 days at room temperature. Isolated cultures were subcultured onto potato dextrose agar (PDA) and single spore culture was carried out to obtain pure strains of Foc TR4. Pure cultures of Foc TR 4 were stored on sterile filter paper for short term storage at $4^{\circ} \mathrm{C}$.

\section{MORPHOLOGICAL CHARACTERISATION}

The fungal isolates were identified morphologically (Leslie \& Summerell 2006). Briefly, monosporic cultures were plated on carnation leaf agar (CLA) and incubated for 4 weeks to induce sporulation (micro- and macroconidia) and the production of reproductive structures (chlamydospores). The spores and reproduction structures were identified and measured using a light microscope (Olympus CX31) equipped with Dino-Eye Eyepiece camera (DinoLite ${ }^{\mathrm{TM}}$ ). Colony colour was observed for each isolates grown on PDA medium after 7 days of incubation.

\section{PATHOGENICITY TEST}

For pathogenicity assay, fungal isolates were grown on PDA for 7 days. By dispensing $15 \mathrm{~mL}$ of sterile distilled water onto the culture plate, the aerial mycelia were gently scrapped to release the spores. The suspension was filtered through two layers of cheesecloth and its spore concentration was adjusted to $10^{8}$ spores $/ \mathrm{mL}$. The pathogenicity test was carried out according to Purwati et al. (2008) with slight modifications. Briefly, soil was gently removed to expose the roots from 2-month-old susceptible banana plants (Musa AAA 'Berangan'). The roots were immersed into the spore suspension for $2 \mathrm{~h}$ before planting them into sterile compost soil. All isolates were tested in four replicates and repeated twice. Banana plants immersed in sterile distilled water served as controls. All plants were fertilised with NPK blue (15N:15P:15K) once a fortnight to ensure leaf wilting was not caused by malnutrition. Severity of wilting was recorded weekly for a period of 8 weeks following the disease scale where 1 indicates no symptom/healthy, 2 denotes initial yellowing mainly on the lower leaves, 3 means yellowing of all the lower leaves including some discoloration on the younger leaves, 4 indicates intense yellowing on all leaves, and 5 means plant dead/complete wilting (Dita et al. 2014). Foc TR4 was re-isolated from symptomatic plants on PDA to fulfill the Koch's postulate. Pathogenicity ratings of Foc towards banana plants were also computed according to Zulperi et al. (2014).

\section{GENOMIC DNA EXTRACTION, PCR AND SEQUENCING}

Total genomic DNA was extracted from 7-day-old fungal mycelia cultured in potato dextrose broth (PDB) according 
to Lin et al. (2009). PCR amplification of partial translation elongation factor, TEF- $1 \alpha$ gene was carried out using EF1 and EF2 primers (O’Donnell et al. 1998). Samples were run in $25 \mu \mathrm{L}$ reaction mixtures with PCR conditions of $95^{\circ} \mathrm{C}$ for $5 \mathrm{~min}, 30$ cycles of $95^{\circ} \mathrm{C}$ for $1 \mathrm{~min}, 57^{\circ} \mathrm{C}$ for 45 $\mathrm{s}, 72^{\circ} \mathrm{C}$ for $1 \mathrm{~min}$, and $72^{\circ} \mathrm{C}$ for $10 \mathrm{~min}$. The PCR products obtained were sent for purification and sequencing (First Base Laboratories, Singapore). PCR amplification using VCG specific primers as developed by Dita et al. (2010) and $\mathrm{Li}$ et al. (2013) was performed to categorise the Foc isolates into VCG01213 and VCG01213/16, respectively. Foc Race 4, specific primer developed by Lin et al. (2009) was used as a control in our study. Primer sequences were as listed in Table 1.

\section{PHYLOGENETIC ANALYSIS}

The TEF1- $\alpha$ sequences were aligned and compared with sequences published by Fourie et al. (2009) using ClustalW multiple sequence alignment programme. Phylogenetic analysis of the sequences was based on maximum likelihood (ML) method by Tamura-Nei model with 1000 bootstraps using MEGA 7.0 software (Tamura et al. 2011).

\section{RESULTS AND DISCUSSION}

In this study, all 17 Foc isolates showed typical morphological characteristics (Table 2) as described by Leslie and Summerell (2006). After 2 weeks of incubation on PDA, the colony colour of Foc cultures was found to be white, pink or purple. Macroconidia were falcate and presented 3 to 4 septates with measurements recorded at 40 to $55 \mu \mathrm{M} \times 3$ to $4 \mu \mathrm{M}$. Microconidia were oval-shaped with no septate measuring at 5 to $13 \mu \mathrm{M} \times 2$ to $3 \mu \mathrm{M}$. Chlamydospores were globose, present in either single or in pairs and produced abundantly in hyphae on the CLA agar surface after 4 weeks of incubation. These key morphological features have confirmed that these isolates were Fusarium oxysporum. Nonetheless, morphological identification is insufficient to clearly distinguish the isolates into formae speciales and physiological race. Therefore, molecular identification using species-specific primers present an alternative approach to rapidly identify and distinguish them (Dita et al. 2010; Lin et al. 2009).
Molecular identification using TR4 specific primers has been carried out. PCR amplicons of $\sim 463$ bp and $\sim 455$ bp were successfully amplified from all 17 Foc isolates using specific primers developed by Dita et al. (2010) and Li et al. (2013). This confirmed these isolates to be TR4 strains (Figure 2) since no PCR amplicons were detected when Race 4 specific primers were used (data not shown).

For the pathogenicity assay, all isolates showed pathogenicity on the susceptible Berangan plants while the control plant remained asymptomatic (Figure 1). Foc was successfully re-isolated from diseased plants. Results from this study also indicated that the Berangan cultivar was susceptible to Foc isolates from different Peninsular Malaysian states with varying degree of aggressiveness, labeled as $\mathrm{H}$ (high), $\mathrm{M}$ (moderate) and L (low) as shown in Table 3 and Figure 1. Generally, isolates from Johor, Pahang and Selangor were either highly or moderately aggressive. Other isolates such as those from Negeri Sembilan and Perak showed distinct high and low virulence levels. Such variation of aggressiveness among Foc isolates was also reported previously from 13 municipalities in Southern Brazil (Cunha et al. 2015).

Foc was known to co-evolve with their plant hosts (Ploetz \& Pegg 1997). As explained by Fourie et al. (2009) and the phylogenetic tree (Figure 3) constructed based on maximum-likelihood model, the Foc isolates in clade B originate from banana genotypes with the ' $\mathrm{B}$ ' genomes with at least one $\mathrm{B}$ chromosome inherited from Musa balbisiana (M.balbisiana $\times$ M. acuminata hybrids) while those in clade A mostly originate from banana genotypes with pure 'A' genomes with all A chromosomes inherited from $M$. acuminata. It was postulated that the ancestors in clade B could have passed on the ability to cause disease to pure and hybrid banana cultivars to its descendants. As shown in Table 1, TR4 strains were isolated from banana cultivars of both pure (AAA and $\mathrm{AA}$ genotypes) and hybrid (ABB and $\mathrm{AAB}$ genotypes) backgrounds which suggested that Foc appeared to have co-evolved with its plant host.

The PCR amplicons from the amplification of the TEF1- $\alpha$ gene had 645 bp of quality sequences to be used for phylogenetic analysis. Accession numbers for each isolate were presented in Table 2. The phylogenetic tree

TABLE 1 . Specific primers used in this study

\begin{tabular}{|c|c|c|c|c|c|}
\hline $\begin{array}{l}\text { Primer } \\
\text { Name }\end{array}$ & Sequence & Function & $\begin{array}{c}\text { Annealing } \\
\text { temperature } \\
\left({ }^{\circ} \mathrm{C}\right)\end{array}$ & $\begin{array}{l}\text { Expected } \\
\text { PCR product } \\
\text { size (bp) }\end{array}$ & Reference \\
\hline Foc-1 & 5'-CAGGGGATGTATGAGGAGGCT-3' & To identify Foc R4 & 68 & 242 & Lin et al. (2009) \\
\hline Foc-2 & 5'-GTGACAGCGTCGTCTAGTTCC-3' & & & & \\
\hline FocTR4-F & 5'-CACGTTTAAGGTGCCATGAGAG-3' & To identify VCG 01213 & 60 & 463 & Dita et al. (2010) \\
\hline FocTR4-R & 5'CGCACGCCAGGACTGCCTCGTGA-3' & & & & \\
\hline 01213/16F1 & 5'-ACGTTTAAGGTGCCATGAGAG-3' & To identify VCG $01213 / 16$ & 64 & 455 & Li et al. (2013) \\
\hline 01213/16R2 & 5'-CCTCGTGAGCCACTTTTTAT-3' & & & & \\
\hline
\end{tabular}




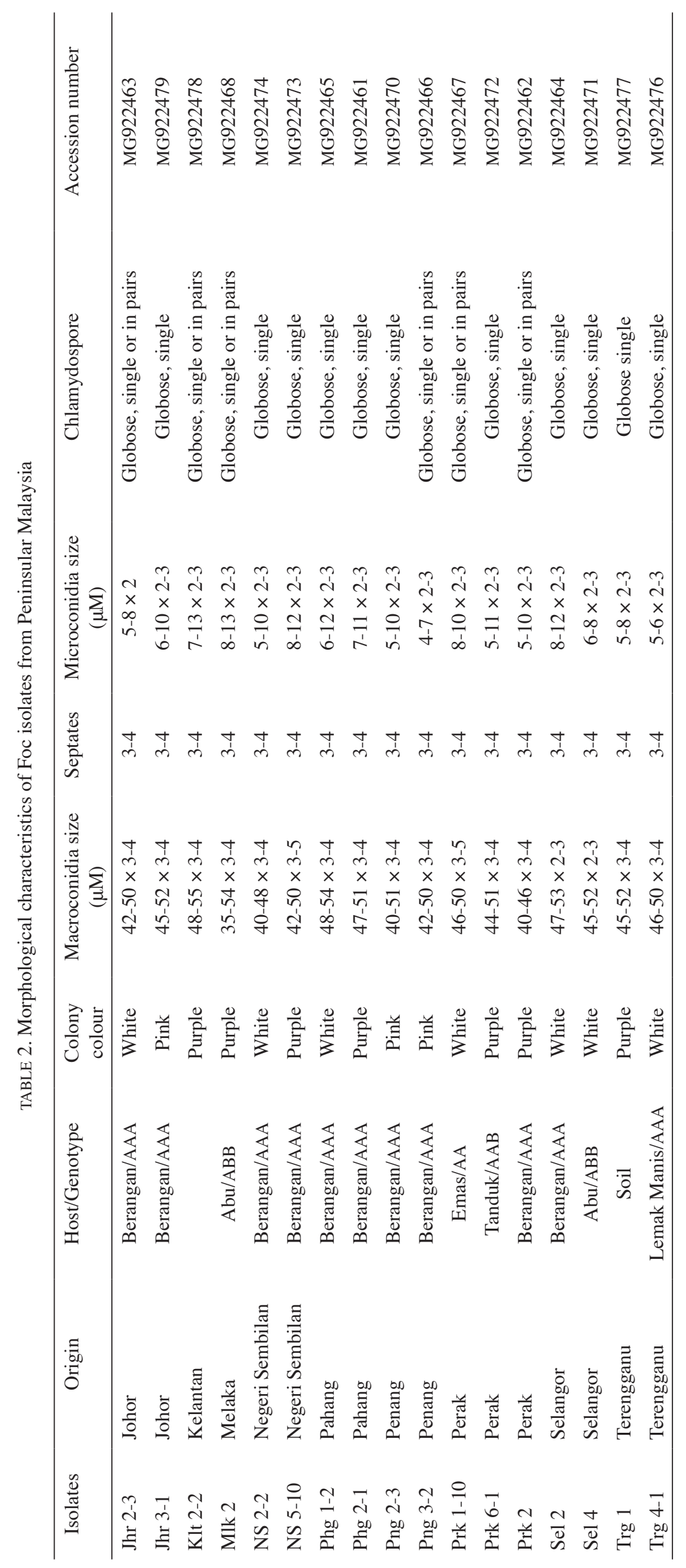




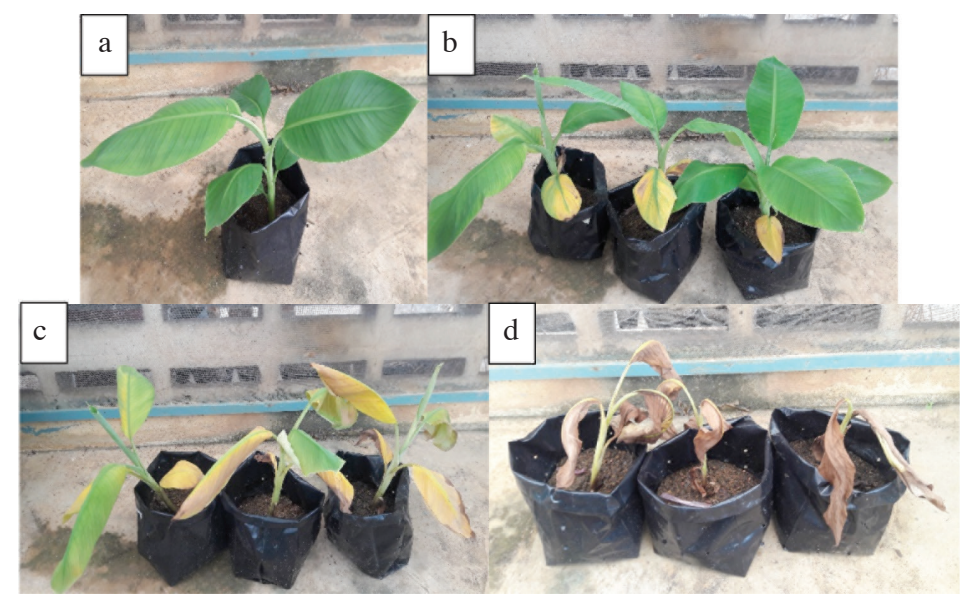

FIGURE 1. Pathogenicity and level of aggressiveness of Foc isolates on susceptible Berangan cultivar after 12 weeks of inoculation. Susceptible plants showing (a) no symptoms, (b) low, (c) medium and (d) high aggressiveness. The rating is based on the leaf wilting score developed by Dita et al. (2014)

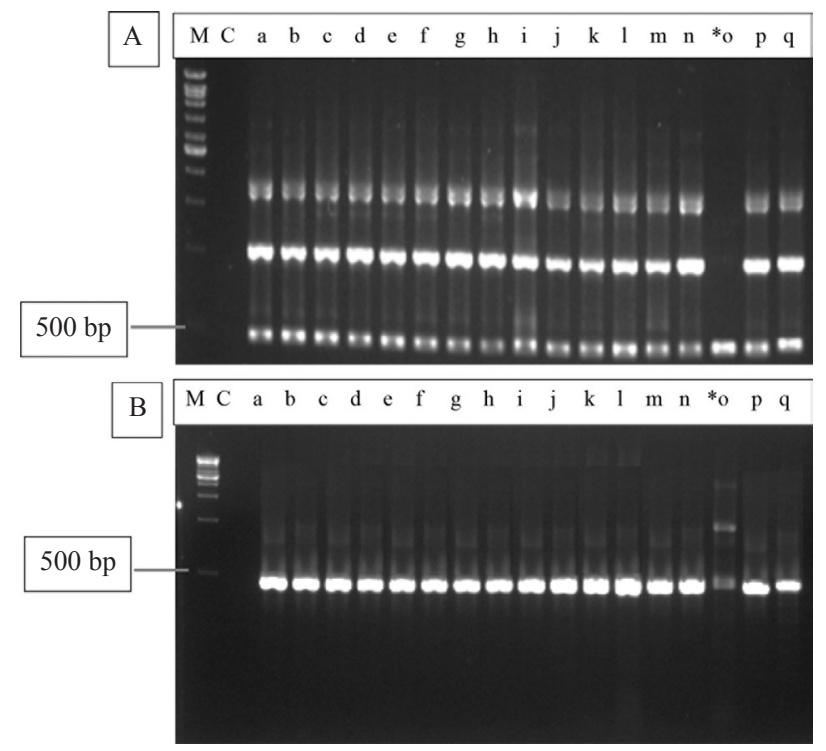

FIGURE 2. PCR amplification of (A) VCG01213/16 specific primers and (B) VCG01213 specific primers for 17 isolates of Foc isolated from various states in Peninsular Malaysia (M - 1 kb DNA ladder; C - No template control; a. Jhr 2-3; b. Jhr 3-1; c. Klt 2-2; d. Mlk 2; e. NS 2-2; f. NS 5-10; g. Phg 1-2; h. Phg 2-1; i. Png 2-3; j. Png 3-2; k. Prk 1-10; 1. Prk 6-1; m. Prk 2; n. Sel 2; o. Sel 4; p. Trg 1; q. Trg 4-1) from Peninsular Malaysia using Foc TR4 specific primers. *Isolate O is the only strain that was categorized as VCG0123/16

(Figure 3) showed that all isolates in this present study and TEF1- $\alpha$ sequences obtained from Fourie et al. (2009) were clustered in clade A. Within clade A, all 17 isolates in this study were classified as belonging to Foc. Our isolates were grouped together (bootstrap value of 64\%) in Lineage $\mathrm{V}$ which consisted of VCGs of 01213, 01213/16,01216 and 0121 irrespective of the geographical region. These VCGs represented Foc strains TR4 and R4 from Malaysia, Indonesia and Taiwan. Meanwhile, outgroups consisting of $F$. commune, $F$. proliferatum var. proliferatum and $F$. phaseoli were clustered in clade B. The TEF1- $\alpha$ gene has been routinely used for species identification of Fusarium spp. and it has shown certain degree of variation within Foc isolates (Fourie et al. 2009; Leong et al. 2010). In this present study, the phylogenetic analysis of the gene sequence did not show variation among the isolates. Our isolates were grouped with isolates from lineage $\mathrm{V}$ (Fourie et al. 2009). It is plausible to hypothesise that our isolates can be assigned to VGGs 01213, 01213/01216 or 01216 and not 0121 since the isolates were initially identified as TR4 strains using species-specific primers. Using VCG specific primers, all 16 Foc isolates were further classified as VCG01213 and only a single strain was grouped as VCG01213/16 which might suggest that VCG 01213 is widely distributed in Malaysia. In contrast, Mostert et al. (2017) reported that Foc isolates from VCG $01213 / 16$ were widespread in Malaysia. In order to verify such differences, vegetative compatibility test has to be 
TABLE 3. Aggressiveness of Foc isolates towards M. acuminata cv. Berangan based on pathogenicity rating and symptom observation after 8 weeks of inoculation

\begin{tabular}{lcl}
\hline Isolates & Pathogenicity rating & Symptoms observed \\
\hline Control ${ }^{*}$ & None & No leaf wilting \\
Jhr 2-3 & H & Plants completely wilted \\
Jhr $3-1$ & M & Three or four leaves wilted \\
Klt 2-2 & L & One or two leaves wilted \\
Mlk 2 & L & One or two leaves wilted \\
NS 2-2 & L & One or two leaves wilted \\
NS 5-10 & H & Plants completely wilted \\
Phg $1-2$ & M & Three or four leaves wilted \\
Phg 2-1 & H & Plants completely wilted \\
Png 2-3 & L & One or two leaves wilted \\
Png 3-2 & M & Three or four leaves wilted \\
Prk 1-10 & H & Plants completely wilted \\
Prk 6-1 & L & One or two leaves wilted \\
Prk 2 & H & Plants completely wilted \\
Sel 2 & M & Three or four leaves wilted \\
Sel 4 & H & Plants completely wilted \\
Trg 1 & M & Three or four leaves wilted \\
Trg 4-1 & L & One or two leaves wilted \\
\hline
\end{tabular}

a H, high (index 4.1-5.0); M, moderately (index 2.6 - 4.0); L, low (index 1.1 - 2.5); 0, none (index 1.0)

*Control plants were inoculated with sterile distilled water instead of Foc spores

carried out in future to categorise the Foc isolates used in this study into appropriate VCGs.

When compared to another study by Leong et al. (2010), phylogenetic analysis using the TEF-1 $\alpha$ did not show significant variations between the isolates used in this study (Figure 3). It is suggested that our isolates are not of multiple origins which might suggest a clonal population structure. Groenewald et al. (2006) reported that mutation in the Foc genome does not frequently occur regardless of the host genotype. Similarly, Costa et al. (2015) also stated that SSR genetic marker analysis of 214 Foc isolates from various regions of Brazil indicated they comprised a clonal population. Most importantly, it is not known if species identification and pathogenicity assay have been performed to ensure that the isolates used in Leong et al. (2010) were pathogenic to banana plants before attempting phylogenetic analysis. For instance, an isolate (B2471N) was not clustered in any of the Foc isolates based on the TEF1- $\alpha$ inferred phylogenetic tree (Leong et al. 2010). This particular isolate remained ambiguous because its pathogenicity and morphological characteristics have not been elucidated in detail. Hence, the inaccuracy in the phylogenetic analysis is evident. This could explain the discrepancies found in our phylogenetic data compared to previous study conducted by Leong et al. (2010).

On the other hand, the isolates demonstrated varying level of aggressiveness although they were genetically similar based on the phylogenetic data. However, there was no correlation found between the variation of aggressiveness in the isolates and the phylogenetic data. Perhaps, the utilisation of DNA regions associated with virulence genes could shed light on the relationship between the genetic variability and aggressiveness level of Foc (Ellis et al. 2016; Sutherland et al. 2013).

\section{CONCLUSION}

Despite the low genetic variability among the Foc isolates, the present phylogenetic data has presented preliminary information about the VCG grouping of our isolates. In order to further validate the genetic variability of the Foc isolates, additional DNA-based techniques such as genetic markers will be employed in the future. Also, the clonal population of Foc isolates in Peninsular Malaysia might be associated to the dissemination of infected corms from a single source. There is also potential for the isolates to co-evolve with banana hosts of pure and hybrid background as indicated in this present study. This information is essential to deploy effective disease management strategies including development of durable resistant cultivars and identification of effective biological control agents against Fusarium wilt of bananas in Malaysia.

\section{ACKNOWLEDGEMENTS}

We would like to thank the Malaysian Department of Agriculture (DOA) for their assistance on disease sampling. The first author is also grateful for the MyBrain15 scholarship provided by the Ministry of Higher Education, Malaysia. This research is funded by Geran Putra Inisiatif Pengajian Siswazah, IPS (Grant No. 9546600).

\section{REFERENCES}

Buddenhagen, I.W. 2009. Understanding strain diversity in Fusarium oxysporum f. sp. cubense and history of introduction of 'Tropical Race 4' to better manage banana production. Acta Horticulturae 828: 193-204.

Costa, S.N., Brangasa, C.A.D., Ribeiro, L.R., Amorim, E.P., Oliveira, S.A.S., Dita, M.A., Laranjeira, F.F. \& Haddad, F. 


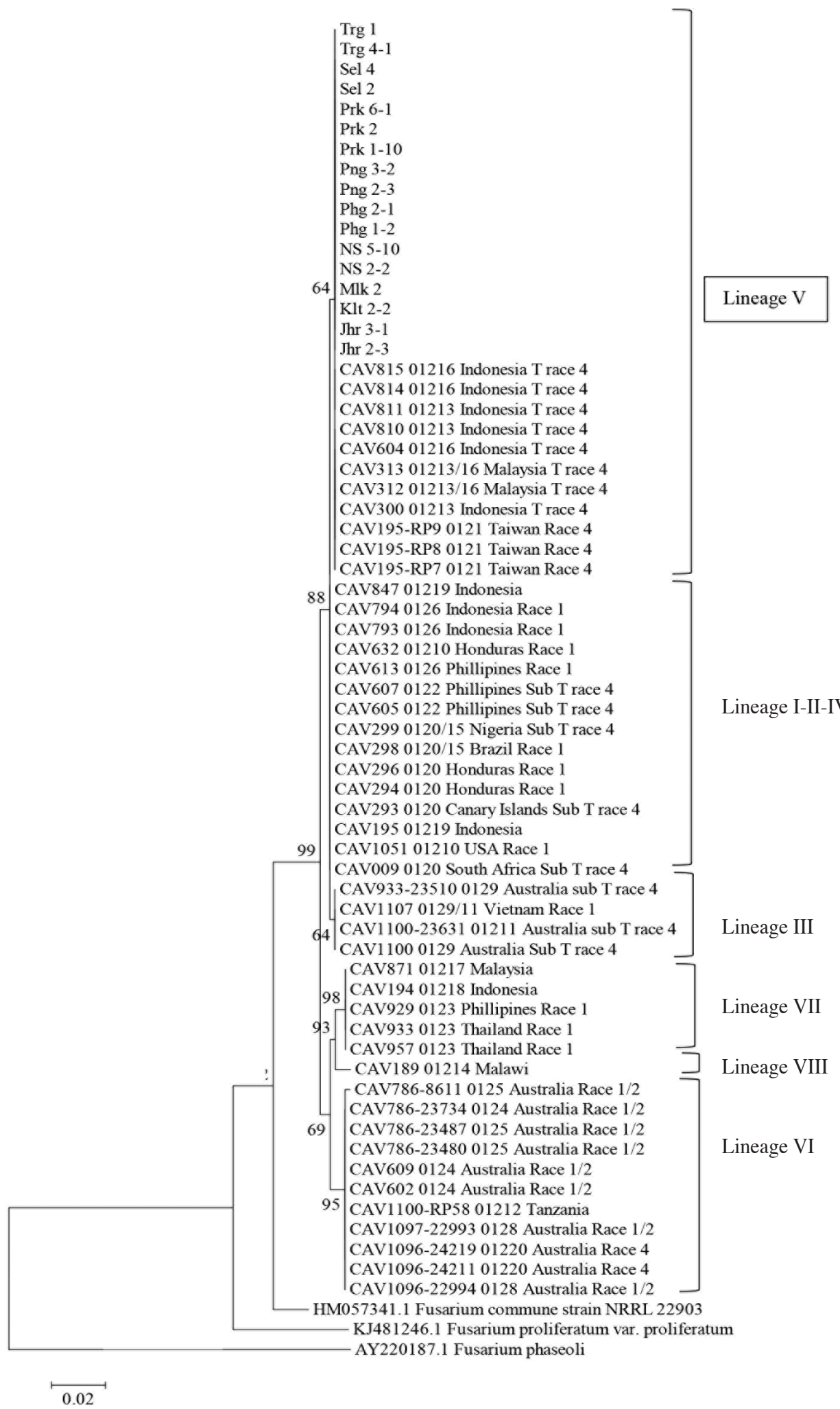

Clade B

Clade B

FIGURE 3. Maximum likelihood phylogenetic tree constructed based on Foc TEF-1 $\alpha$ sequence data. The analysis was carried out with the TEF- $1 \alpha$ sequences of our sample isolates combined with those published by Fourie et al. (2009) as well as sequences from F. commune strain NRL 22903 (HM057341.1), F. proliferatum var. proliferatum (KJ481246.1) and $F$. phaseoli (AY220187.1). Numbers at the nodes indicate bootstrap support (>50\%). The scale bar corresponds to 0.02 nucleotide substitutions per site. The tree is rooted with Fusarium phaseoli 
2015. Genetic structure of Fusarium oxysporum f. sp.cubense in different region of Brazil. Plant Pathology 64: 137-146.

Cunha, C.M., Hinz, R.H., Pereira, A., Tcacenco, F.A. \& Stadnik, M.J. 2015. Aggressiveness and genetic diversity of Fusarium oxysporum f. sp. cubense from Santa Catarina, Southern Brazil. Tropical Plant Pathology 40: 326-334.

Dita, M.A., Waalwijk, C., Buddenhagen, I.W., Souza Jr., M.T. \& Kema, G.H.J. 2010. A molecular diagnostic for tropical race 4 of the banana fusarium wilt pathogen. Plant Pathology 60(2): 348-357.

Ellis, M.L., Lanubile, A., Garcia, C. \& Munvold, G.P. 2016. Association of putative fungal effectors in Fusarium oxysporum with wilt symptoms in soybean. Phytopathology 106(7): 762-773.

Fourie, G., Steenkamp, E.T., Gordon, T.R. \& Vijoen, A. 2009. Evolutionary relationships among the Fusarium oxysporum f. sp. cubense vegetative compatibility groups. Applied Environmental Microbiology 75: 4770-4781.

Groenewald, S., Van der Berg, N., Marasas, W.F.O.\& Viljoen, A. 2006. The application of high-throughput, AFLP in assessing genetic diversity in Fusarium oxysporum f. sp. cubense. Mycology Research 110: 297-305.

Katan, T. 1999. Current status of vegetative compatibility groups in Fusarium oxysporum. Phytoparasitica 27: 72-77.

Komada, H. 1975. Development of a selective medium for quantitative isolation of Fusarium oxysporum from natural soil. Plant Protection Research 8: 114-125.

Kumar, B.H., Shankar, U.A.C., Kini, R.K., Prakash, H.S. \& Shetty, S.H. 2006. Genetic variation in Fusarium oxysporum f. sp. cubense isolates based on random amplified polymorphic DNA and intergenic spacer. Archives of Phytopathology and Plant Protection 39: 151-160.

Leong, S.K., Latiffah, Z. \& Baharuddin, S. 2010. Genetic diversity of Fusarium oxysporum f.sp. cubense isolates from Malaysia. African Journal of Microbiology Research 4: 1026-1037.

Leslie, J.F. \& Summerell, B.A. 2006. The Fusarium Laboratory Manual. UK: Wiley Blackwell.

Li, C.Y., Mostert, G., Zuo, C.W., Beukes, I., Yang, Q.S., Sheng, O., Kuang R.B., Wei, Y.R., Hu, C.H., Rose, L., Karangwa, P., Yang, J., Deng, G.M., Liu, S.W., Gao, J., Viljoen, A.\& Yi, G.J. 2013. Diversity and distribution of the banana wilt pathogen Fusarium oxysporum f. sp. cubense in China. Fungal Genomics and Biology doi: 10.4172/2165-8056.1000111.

Lin, Y.H., Chang, J.Y., Liu, E.T., Chao, C.P., Huang, J.H. \& Chang, P.F.L. 2009. Development of a molecular marker for specific detection of Fusarium oxysporum f. sp. cubense race 4. European Journal of Plant Pathology 123: 353-365.

Mostert, D., Molina, A.B., Daniells, J., Fourie, G., Hermanto, C., Chao, C.P., Fabregar, E., Sinohin, V.G., Masdek, N., Thangavelu, R., Li, C., Yi, G., Mostert, L. \& Viljoen, V. 2017. The distribution and host range of the banana Fusarium wilt fungus, Fusarium oxysporum f. sp. cubense, in Asia. PLoS ONE 12: e0181630.

O’Donnell, K., Kistler, H.C., Cigelnik, E. \& Ploetz, R.C. 1998. Multiple evolution origins of the fungus causing Panama disease of banana: Concordant evidence from nuclear and mitochondrial gene genealogies. Applied Biological Sciences 95: 2044-2049.

Ploetz, R.C. 2015. Fusarium wilt of banana. Phytopathology 105: 1512-1521.
Ploetz, R.C. 2006. Fusarium wilt of banana is caused by several pathogens referred to as Fusarium oxysporum f. sp. cubense. Phytopathology 96: 653-656.

Ploetz, R.C. \& Pegg, K.G. 1997. Fusarium wilt of banana and Wallace's line: Was the disease originally restricted to his Indo-Malayan region? Australasian Plant Pathology 26: 239-249.

Ploetz, R.C., Herbert, J., Sebasigari, K., Hernandez, J.H., Pegg, K.G., Ventura, J.A. \& Mayato, L.S. 1990. Importance of fusarium wilt in different banana-growing regions. In Fusarium Wilt of Banana: Proceedings of International Conference on Fusarial Wilt of Banana 1989, edited by Ploetz, R.C. USA: APS Press. pp. 9-26.

Puhalla, J.E. 1985. Classification of strains of Fusarium oxysporum on the basis of vegetative compatibility. Canadian Journal of Botany 63: 179-183.

Purwati, R.D., Hidayah, N., Sudjindro. \& Sudarsono. 2008. Inoculation methods and conidial densities of Fusarium oxysporum f. sp. cubense in Abaca. HAYATI Journal of Biosciences 15: 1-7.

Stover, R.H. 1972.Banana, Plantain and Abaca Diseases. Surrey, England: Commonwealth Mycological Institute.

Sutherland, R., Viljoen, A., Myburg, A.A. \& Van den Berg, N. 2013. Pathogenicity associated genes in Fusarium oxysporum f. sp. cubense race 4. South African Journal of Science 109: $1-10$.

Tamura, K., Peterson, D., Peterson, N., Stecher, G., Nei, M. \& Kumar, S. 2011. MEGA 5: Molecular evolutionary genetics analysis using maximum likelihood, evolutionary distance, and maximum parsimony methods. Molecular Biology and Evolution 28: 2731-2739.

Visser, M., Gordon, T., Fourie, G. \& Viljoen, A. 2010. Characterisation of South African isolates of Fusarium oxysporum f. sp. cubense from Cavendish Bananas. South African Journal of Science 106: 1-6.

Zulperi, D., Sijam, K., Ahmad, M., Zainal, A., Awang, Y. \& Sulaiman Rahid, T. 2014. Occurrence of Ralstonia solanacearum race 2 biovar 1 associated with moko disease of banana (Musa paradisiaca cv. Nipah) in Malaysia. Journal of Phytopathology 162: 697-702.

Clement Kiing Fook Wong, Dzarifah Zulperi* \& Ganesan Vadamalai

Department of Plant Protection

Faculty of Agriculture

Universiti Putra Malaysia

43400 UPM Serdang, Selangor Darul Ehsan Malaysia

Noor Baity Saidi \& Chui Yao Teh

Department of Cell and Molecular Biology

Faculty of Biotechnology and Biomolecular Sciences

Universiti Putra Malaysia

43400, UPM Serdang, Selangor Darul Ehsan

Malaysia

*Corresponding author; email: dzarifah@upm.edu.my

Received: 3 November 2018

Accepted: 12 May 2019 